\title{
DRIVING FORCE OF ORGANIC FERTILIZER USE IN CENTRAL RIFT VALLEY OF ETHIOPIA: INDEPENDENT DOUBLE HURDLE APPROACH
}

\author{
Aemro T. Terefe ${ }^{I}$, Musa H. Ahmed
}

\begin{abstract}
The objective of this study was to identify the important factors that influence both adoption and level of use of organic fertilizer among smallholder farmers in the Central Rift Valley of Ethiopia using a primary data collected from 161 sample respondents. An independent double hurdle model was used to address the objectives of the study on the assumption that adoption and level of organic fertilizer use by are two independent decisions influenced by different factors. Empirical estimates of the first hurdle reveals that literacy status of the head, livestock holding, frequency of extension contact, distance to market and slope of the plot are statistically significant decision variables that affect the probability of adopting organic fertilizer. Meanwhile, estimates of the second hurdle revealed that, the extent of use of organic fertilizer was determined by livestock holding, access to credit distance to the market and slope of plot. This indicates that factors that affect adoption are not necessarily the same as those that influence intensity. Therefore, it is important to consider both stages in evaluating strategies aimed at promoting the adoption and use of organic fertilizer.
\end{abstract}

Key words: Adoption, Level of use, Organic fertilizer, Double hurdle model, Ethiopia

JEL: $Q 16, M 24$

\section{Introduction}

Half of the population of sub-Saharan-Africa (SSA) lives in poverty (AfDB, 2011). Since majority of them relies on subsistence agriculture for their own food and as a source of income (Larsen et al., 2014), improving the performance of the agricultural sector is the main pathway out of poverty and to improve the livelihood of most of the people in this region (Dawson et al., 2016). However, the agriculture sector of most of the SSA countries has not been able to ensure food security in both at the national and the household level (Bezu et al., 2014). Several biophysical and socioeconomic factors have been identified as key

1 Aemro T. Terefe, Lecturer, Haramaya University, School of Agricultural Economics and Agribusiness, P.O. Box no. 95, Dire Dawa, Ethiopia, E-mail: aemrot@gmail.com

2 Musa H. Ahmed, Lecturer, Haramaya University, School of Agricultural Economics and Agribusiness, P.O. Box no. 95, Dire Dawa, Ethiopia, E-mail: musahasen@gmail.com

EP 2016 (63) 4 (1265-1279) 
constraints limiting productivity growth in agriculture in SSA (Misiko and Ramisch 2007). Among others, soil fertility depletion is considered as the main biophysical limiting factor for increasing per capita food production in SSA (Ajayi et al., 2007; Beedy et al., 2010). The farming of SSA is characterized by poor soil fertility and low levels of agricultural technology use (Teklewold et al., 2013).

Among countries in the SSA, Ethiopia is known for its structural food insecurity, poverty, fast population growth and accelerated environmental degradation (Pender et al., 2007). Currently the agricultural sector in Ethiopia is registering remarkable gains; from 2006/07 to $2013 / 14$ production of cereals increased by $45 \%$ and productivity grew by $22 \%$ (ATA, 2014). Despite these staggering achievements, there is still more work to be done. The country remains to be one of the poorest countries in the world. In 2011 alone, Productive Safety Net Program supported 7.4 million people, whereas an additional 4.5 million people were requiring emergency humanitarian assistance (FEWS NET, 2011). If the country continues on its current productivity path, food insecurity could climb to over 50 million people, reducing GDP per farming household by nearly 20\% by 2020 (ATA, 2010). Hence, being an agriculturally dependent country with a food deficit, increasing crop production and productivity is not a matter of choice rather it is a must to attain (Spielman et al., 2010).

Agricultural growth and development is not possible without yield-enhancing technological options since expanding the area under cultivation to meet the increasing food needs of growing populations is no longer possible (Kassie et al., 2011).). Hence, Adoption of productivity enhancing technologies is crucial to increase agricultural productivity and reduce poverty. (Becerril \& Abdulai, 2010; Minten \& Barrett, 2007). Nevertheless, there is a risk of a tradeoff between the attempts to increase the productivity through "modernization packages" that combine improved seed varieties with agrochemicals (such as chemical fertilizers and pesticides) and the resulting stress that these have on ecosystem services. Otherwise not properly utilized, agrochemicals can cause significant harm to the environment and human health (Teklewold et al., 2013). Hence, farmers and policy makers must turn their attention to an alternative agricultural technology that uses less agrochemical.

Organic fertilization systems can to increase crop productivity and increase the sustainability of agro-ecosystems (García-Orenes et al., 2013; Macci et al., 2013). The application of organic fertilizer increases soil organic matter content, and this leads to improved water infiltration and water holding capacity as well as an increased soil carbon content (Kassie et al., 2009; Manyong et al., 2006; Girmay et al., 2008). Notwithstanding its benefits, the adoption rate of organic fertilizer is still low in Ethiopia. For instance, in 2014/15 production season only $10.96 \%$ of cultivated land was utilizing organic fertilizer (CSA, 2015), even though the country has great potential in this regard because of surplus labor and huge livestock potential.

Therefore, it is essential to look in to the important factors that are affecting farmers' decision to adopt organic fertilizer. Although there have been some economic studies on crop-livestock farming systems in the past (McIntire et al., 1992), not that many of the previous studies have identified the causal of adopting organic fertilizer on crop production on smallholder farms. 
The purpose of this study is, therefore, to identify the determinants of adoption and the extent of use of organic fertilizer application on crop production in Central Rift Valley of Ethiopia.

\section{Research Methodology}

\section{Study area, sampling procedure and source}

The study was conducted in Central Rift Valley of Ethiopia specifically in the Arsi Negelle district of Oromia. The soils of the area are lightweight, friable loam and clay loam. The main crops grown in the area include wheat (Triticum aestivum), maize (Zea mays), teff (Eragrostis tef), barley (Hordeum vulgare), sorghum (Sorghum bicolor) and onion (Allium cepa). According to CSA (2011), Arsi Negelle district has a total population of 303,223 of which 150,245 are male and 152,978 are females. The average family size for the district was 5.2 (5.3 for urban and 5.1 for rural). The population density of the district was 236.7 persons per $\mathrm{km}^{2}$.

The data for this study was generated through primary and secondary data. Primary data were collected through a household survey conducted in three peasant associations of Arsi Negelle district. Then a total of 161 respondents were selected randomly from the three peasant associations proportional to the size of the population in each of them.

\section{Empirical models}

Farmers' adoption behavior especially in developing countries is influenced by a complex set of socio-economic, demographic, technical and institutional factors. Hence, modeling farmers' response to organic fertilizer adoption has become important both theoretically and empirically. Our data shows that farm households in Arsi Negelle district differ in the proportion of using organic fertilizer. Some sample households are non-adopters of organic fertilizer; the identified use of organic fertilizer for such households is equal to zero. Zero adoption is one of the major problems for any modelling effort to address. As noted in Greene (2003), a dependent variable that has a zero value for a significant fraction of the observations requires a censored regression model because standard OLS results a biased and inconsistent parameter estimates.

Tobit model developed by Tobin (1958) has been widely used to deal with censored observations. This model is employed by many researchers (including Arslan et al., (2014) Kalinda et al., (2014) Obayelu et al., (2016) and Fikru, 2009) because; it has an advantage over other models such as (Linear Probability Models, Logit, and Probit) in that, it reveals both the probability of willingness to adopt and level of adoption. However, this model is very restrictive. One reason is that, it attributes the censoring to a standard corner solution. Secondly, Tobit model has been shown to be inadequate to characterize the two processes in adoption: the adoption process and extent of adoption process. This is because; any variable, which increases the probability of non-zero extent, is assumed to also increase the mean of the positive adoption, which is not always reasonable.

In principle, the decisions on whether to adopt and how much to adopt can be made jointly EP 2016 (63) 4 (1265-1279) 
or separately (Berhanu and Swinton 2003). The double-hurdle model, Cragg (1971), can overcome this shortfall. The double-hurdle model is applied in such a way that, both hurdles (the decision for adoption and extent of adoption) have equations associated with them, incorporating the effects of farmer's characteristics and circumstances. Such explanatory variables may appear in both equations or in either of one. Most importantly, a variable appearing in both equations may have opposite effects in the two equations (Teklewold et.al. 2006).

The double-hurdle model is a parametric generalization of the Tobit model, in which two separate stochastic processes determine the decision to adopt and the extent of adoption of technology. The double-hurdle model has an adoption (D) equation given by:

$$
\begin{array}{ll}
D_{i}=1 \ldots . . \text { if } & D_{i}^{*}>0, \\
D_{i}=0 \ldots . . \text { if } \quad & D_{i}^{*} \leq 0 \\
D_{i}^{*}=\alpha Z_{i}+\mu_{i} &
\end{array}
$$

Where, $D_{i}^{*}=$ The latent variable that takes the value 1 if the farmer uses organic fertilizer and 0 otherwise; $Z_{i}=Z_{i}=Z_{i}=$ Vector of independent variables affecting the adoption of organic fertilizer; $\alpha=$ vector of unknown parameters; $u_{i}=$ residuals that are independently and normally distributed with mean zero and a constant variance $\sigma^{2} ; \mathrm{i}=1,2, \ldots \mathrm{n}$. (n is the number of observation).

The second hurdle involves an outcome equation, which uses a truncated model to determine the level of adoption of an organic fertilizer in question. This second hurdle uses observations only from those respondents who indicated a positive value of use of an organic fertilizer. The truncated model, which closely resembles the Tobit model, is expressed as:

$$
\begin{aligned}
& Y_{i}= \begin{cases}Y_{i}^{*} & f \quad Y_{i}^{*}>0 \text { and } D_{i}^{*}>0 \\
0 & \text { otherwise }\end{cases} \\
& Y_{i}^{*}=\beta X_{i}+\varepsilon_{i}
\end{aligned}
$$

Where $\mathrm{Y}_{\mathrm{i}}$ is the observed response on the extent of adoption of organic fertilizer, $\mathrm{X}_{\mathrm{i}}$ is a vector of explanatory variables hypothesized to influence intensity of technology use, $\beta$ is a vector of parameters and $\varepsilon_{i}$ is the standard error term.

The decision on whether or not to adopt organic fertilizer and how much of that organic fertilizer to use can be jointly modelled if they are made simultaneously by the household; independently modelled if they are made separately; or sequentially modelled if one is made first and affects the other one as in the dominance model (John et al., 2009). 
The error terms, are distributed as follows:

$$
\left\{\begin{array}{l}
\mu_{i} \approx N(0,1) \\
\varepsilon_{i} \approx N\left(0, \delta^{2}\right)
\end{array}\right\}
$$

The model is said to be a dependent model if there is a relationship between the decision to adopt and the extent of adoption. This relationship can be expressed as follows:

$$
\rho=\frac{\operatorname{Cov}\left(\mu_{i} \varepsilon_{i}\right)}{\sqrt{\operatorname{Var}\left(\mu_{i}\right) \operatorname{Var}\left(\varepsilon_{i}\right)}}
$$

If $\rho=0$ and there is dominance (the zeros are only associated to non-adoption, not standard corner solutions) then the model decomposes into a Probit for adoption decision and truncated for the intensity of adoption on organic fertilizer (John et al., (2009)).

Following Smith (2003) we assume that the error terms $\mu_{i}$ and $\varepsilon_{i}$ are independently and normally distributed. Finally, the observed variable in a double-hurdle model is

$$
Y_{i}=D_{i} Y_{i}^{*}
$$

The Log likelihood function for the double hurdle model is given by

$$
\log L=\sum_{0} \ln \left[1-\phi \alpha Z_{i}\left(\frac{\beta X_{i}}{\sigma}\right)\right]+\sum_{+} \ln \left[\phi \alpha Z_{i} \frac{1}{\sigma} \varphi\left(\frac{Y_{i}-\beta X_{i}}{\sigma}\right)\right]
$$

Where $\phi$ denotes the standard normal CDF (Univariate or Multivariate) and $\varphi$ is the univariate standard normal PDF. $Z_{i} X_{i} X_{i}, X_{i} \beta, \alpha, \sigma$ as defined earlier. Under the assumption of independent between the error terms $\mu_{i}$ and $\varepsilon_{i} \varepsilon_{i} \varepsilon_{i}$, the model (as originally proposed by Cragg, (1971) is equivalent to a combination of a truncated regression model and a univariate

probit model. The Tobit model arises if $\lambda=\frac{\beta}{\sigma}$ and $\mathrm{Z}=\mathrm{X}$

A simple test for the Double hurdle modal against the Tobit model can be examined. It can be shown that the tobit log- likelihood is the sum of the log-likelihood of the truncated as well as the probit models. Therefore, one simply has to estimate the truncated regression model, the tobit model and the probit model separately and use a likelihood ratio (LR) test. The LR statistic can be computed using (Green, 2003).

$$
\Gamma=-2\left[\ln L_{T}-\left(\ln L_{p}+\ln L_{T R}\right)\right] \approx \chi_{k}^{2}
$$

EP $2016(63) 4(1265-1279)$ 
Where $L_{T}=$ Likelihood for the tobit model; $L_{P}=$ likelihood for the probit model; $L_{R}=$ likelihood for the truncated model; and $\mathrm{k}$ is the number of independent variables in the equations.

If the test statistics is written as $H_{0}: \lambda=\frac{\beta}{\sigma} \quad$ and $\quad \lambda \neq \frac{\beta}{\sigma} . \mathrm{H}_{0}$ will be rejected on a specified level of significance level, if $\Gamma>\chi_{k}^{2}$.

\section{Results and Discussion}

\section{Descriptive statistics}

From annex table the t-test and chi-square statistics have made for selected variables about adoption status of the surveyed households. From the 161 farm households, $47.32 \%$ sample respondents were adopters of organic fertilizers. Average age of sample household head is about 40 and 45 years with non-adopters and adopters, respectively. The analysis of the data shows that there is a significant mean difference between age of adopters and nonadopters. Family size is about five persons for non-adopters and six for adopters. This simple comparison of the two groups of households is explicitly articulated as follows.

Table 1. Descriptive statistics of continuous variables included in the double hurdle model

\begin{tabular}{|l|l|l|l|l|}
\hline Variables & Non adopter(0) & Adopter(1) & Total & t-test \\
\hline Age of household & $39.67(1.42)$ & $45.03(1.69)$ & $43.34(0.87)$ & $-2.93^{* * *}$ \\
\hline Family size & $4.92(0.31)$ & $6.2(0.19)$ & $5.8(0.17)$ & $-3.55^{* * *}$ \\
\hline Experience & $17.24(1.12)$ & $22.9(1.07)$ & $21.11(0.84)$ & $-3.24^{* * *}$ \\
\hline Off/no farm income & $595.49(229.61)$ & $403.23(162.24)$ & $464.14(132.37)$ & 0.67 \\
\hline Cultivated land & $1.27(0.1)$ & $2.27(0.15)$ & $1.95(0.11)$ & $-4.36^{* * *}$ \\
\hline Livestock holding & $4.45(0.64)$ & $11.87(1.41)$ & $9.52(1.02)$ & $-3.51^{* * *}$ \\
\hline Extension contact & $34.06(2.4)$ & $46.61(1.2)$ & $42.63(1.21)$ & $-5.23^{* * *}$ \\
\hline Distance to nearest market & $4.27(0.32)$ & $3.4(0.15)$ & $3.67(0.14)$ & 2.79 \\
\hline Distance of plot from home & $0.96(0.15)$ & $1.17(0.08)$ & $1.11(0.07)$ & $-1.33^{*}$ \\
\hline & & & & \\
\hline
\end{tabular}

Note: Numbers out \& in parenthesis represent Mean and Standard error, respectively; *, ** and *** statistically significant at $10 \%, 5 \%$ and $1 \%$ probability level, respectively.

Source: model output based on survey data, 2012/13, N=161 
Table 2. Descriptive statistics of dummy variables included in the double hurdle model

\begin{tabular}{|c|c|c|c|c|}
\hline \multirow{2}{*}{ Variables } & \multicolumn{2}{|c|}{ Adoption decision } & \multirow{2}{*}{ Total } & \multirow{2}{*}{$\begin{array}{l}\chi 2 \text { (chi- } \\
\text { square) }\end{array}$} \\
\hline & Non adopter(0) & Adopter(1) & & \\
\hline \multicolumn{5}{|l|}{ Sex of household } \\
\hline Female & $2(1.26)$ & $7(4.34)$ & $9(5.6)$ & \multirow{2}{*}{0.533} \\
\hline Male & $49(30.42)$ & 103(63.98) & $152(94.4)$ & \\
\hline \multicolumn{5}{|c|}{ Educational status of household } \\
\hline Illiterate & $20(12.42)$ & $46(28.57)$ & $66(40.99)$ & \multirow{2}{*}{0.76} \\
\hline Literate & $31(19.26)$ & $64(39.75)$ & $95(59.01)$ & \\
\hline \multicolumn{5}{|l|}{ Credit access } \\
\hline No & $36(22.36)$ & $74(45.96)$ & $110(68.32)$ & \multirow{2}{*}{0.75} \\
\hline Yes & $15(9.32)$ & $36(22.36)$ & $51(31.68)$ & \\
\hline \multicolumn{5}{|l|}{ Slope of plot } \\
\hline Flatter & $31(19.25)$ & $92(57.14)$ & 123(76.39) & \multirow{2}{*}{0.72} \\
\hline Steeper & $17(10.56)$ & $21(13.04)$ & $38(23.61)$ & \\
\hline
\end{tabular}

Note: Numbers out and in parenthesis represent frequency and percents, respectively

Source: model output based on survey data, 2012/13, $N=161$

\section{Econometric results}

Independent double hurdle model estimation assumes that the two error terms from the two hurdles are normally distributed and uncorrelated. This implies that the two-stage decision of adoption and optimum organic fertilizer use intensity are done independently by respondents. The result of the model revealed that the error terms were uncorrelated. This implies that factors that influence farming households' decision to adopt organic fertilizer were unassociated with the decision variables in the second hurdle involving optimal use of organic fertilizer technology. This result confirmed the relevance of the double hurdle model used in this study. In here, we only discussed statistically significant variables; the rest is annexed in the appendix. 
Table 3. Parameter estimates of Cragg's double hurdle model for use of adoption of organic fertilizer use and organic fertilizer use intensity.

\begin{tabular}{|c|c|c|c|c|c|c|}
\hline \multirow[b]{2}{*}{ Variables } & \multicolumn{3}{|c|}{$\begin{array}{l}\text { Adoption decision } \\
\text { (Probit output) }\end{array}$} & \multicolumn{3}{|c|}{$\begin{array}{l}\text { Organic fertilizer use intensity } \\
\text { (Truncated )output }\end{array}$} \\
\hline & Coef. & Std. Err. & $\begin{array}{l}\text { Marginal } \\
\text { Effect }\end{array}$ & Coef. & Std. Err. & $\begin{array}{l}\text { Marginal } \\
\text { Effect }\end{array}$ \\
\hline Age of the head & -0.003 & 0.028 & -0.003 & -0.135 & 0.264 & -0.135 \\
\hline Education & $0.100^{*}$ & 0.123 & 0.176 & 1.086 & 1.052 & 1.086 \\
\hline Family size & -0.003 & 0.078 & -0.003 & 0.988 & 0.653 & 0.988 \\
\hline Experience & 0.030 & 0.028 & 0.030 & 0.206 & 0.250 & 0.206 \\
\hline Off/nonfarm income & 0.000 & 0.000 & 0.000 & 0.001 & 0.001 & 0.001 \\
\hline Size of cultivated land & 0.133 & 0.266 & 0.133 & -1.005 & 1.516 & -1.004 \\
\hline Size of livestock (TLU) & $0.125 * * *$ & 0.043 & 0.125 & $0.564 * * *$ & 0.136 & 0.564 \\
\hline Extension contact & $0.058 * * *$ & 0.013 & 0.058 & $0.385^{* * *}$ & 0.117 & 0.385 \\
\hline Training & 0.087 & 0.313 & 0.087 & 0.041 & 2.815 & 0.041 \\
\hline Credit & 0.055 & 0.288 & 0.055 & $4.653^{*}$ & 2.534 & 4.653 \\
\hline Distance to the market & $-0.139 *$ & 0.078 & -0.139 & $-1.826^{* * *}$ & 0.687 & -0.0182 \\
\hline Plot size & 0.539 & 0.787 & 0.539 & $0.1964 * * *$ & 5.978 & 0.196 \\
\hline Soil fertility & 0.491 & 0.374 & 0.491 & -1.787 & 3.314 & -1.787 \\
\hline Slope of the plot & $-0.828 * *$ & 0.370 & -0.828 & -4.262 & 3.507 & -4.262 \\
\hline Cons & -2.550 & 1.988 & -2.550 & -9.297 & 16.852 & -9.297 \\
\hline /sigma & & & & 13.015 & 0.928 & \\
\hline
\end{tabular}

$* * *, * *$ and $*$ indicate significance at $1 \%, 5 \%$ and $10 \%$ levels, respectively.

Source: model output based on survey data, 2012/13, $N=161$

Educational status: As expected, being literate household head was positively and significantly related to the adoption decision of organic fertilizer at $10 \%$. This result is plausible, since education increases the capacity of farm households to acquire information and knowledge of organic fertilizer and promote the decision to use it on his/her farm. The probit model result indicated that being literate farm households head will increase adoption decision of organic fertilizer in crop production by $17.6 \%$. This might be due to the fact that an educated farmer would know the advantages of organic fertilizer and would want to enjoy them. This result is in line with the earlier findings of Ochi and Malumfashi (2005), Ofuoku et al. (2008).

Total Livestock holding: Consistent with a priori expectation, livestock holdings found to affect both the probability of participation and the extent of organic fertilizer use positively and significant at less than $1 \%$. This is due to the fact that the main source of organic fertilizer is livestock manure and households who have livestock could apply organic fertilizer more 
than those without livestock. This is in line with the findings of Chilot (2007). Our Double hurdle model estimation indicates that a one unit increase in total livestock holdings increase the probability of participation by $12.57 \%$ and increases the level of application of organic fertilizer by $5.63 \%$ among the participants.

Extension contact: Extension contact had the expected positive and significant effect at less than $1 \%$ on probability of adoption and the intensity of organic fertilizer technology. This implies that organic fertilizer adoption by the small-scale farmers in the study area would depend significantly on the information they get through the extension agents and the frequency of contact. This assumes that extension agent creates more impact on technology adoption as the frequency of contact with farmer increases. This is similar to the findings of Ofuoku et al. (2005).

Access to credit: Having access to credit had the expected positive and significant effect at less than $10 \%$ on intensity of adopting organic fertilizer. Access to affordable credit increases financial resources of farmers and their ability to meet transaction costs associated with various organic fertilizers to solve financial constraints, which is similar to the results of Abay and Assefa (2004). If farmers can get access to credit, they can purchase livestock for the purpose indirect use of organic fertilizer (manure). According to the results of the model, farmers who get credit were about $460.7 \%$ more likely to adopt organic fertilizer technology than those who face credit constraint.

Distance from the market: The average distance from the market was also one of the variables hypothesized to affect the decision to use and the extent use of organic fertilizer. Distance from market turned out to be positively and statistically significant at $10 \%$ and $1 \%$ associated with the decision of participation and the level of adoption of organic fertilizer respectively. However, it had a negative effect on adoption and the extent of application of organic fertilizer, as expected. Proximity to market is an important determinant, presumably because the market serves as a means of exchanging information with other farmers. When farmers are far from the market, the transaction cost for acquiring input and output will be high and this will, in turn, reduce the relative advantage of organic fertilizer use. Our results indicated that, a one-kilometer increase in distance of market reduces the probability to adoption and intensity by $13.9 \%$ and $68.7 \%$ respectively.

Plot size: The positive relationship between plot size and organic fertilizer adoption decision that was evident in the model implies that in the study area, small-scale farmers are more likely to choose farm yard manure adoption as their farm size increases though it is insignificant. Thus plot size turned out to be a major determinant of farm yard manure adoption level. This supports the views of Ofuoku et al. (2008) on plot size.

Slope of plot: The other important factor in terms of decisions to adopt organic fertilizer was average slope of plot. The variable was negatively significant at less than $5 \%$ level on the decision of adoption. The possible reason could be as sloppier plots are susceptible for soil erosion; the return from them will be smaller as compared to the land which is flatter. As the result farmers might prefer to invest on flatter plot than sloppier plots since it provides them 
higher return. In addition to this, if the plot becomes sloppy farmers do not apply manure due to the fear that it will be washed out and affect the neighbors' plots and the environment.

\section{Conclusion and Policy Implications}

The objective of this paper was to understand the determinants of adoption and intensity of organic fertilizer in Central Rift Valley of Ethiopia. This is achieved using an independent double hurdle model. About $47 \%$ of the farmers adopt organic fertilizer, which is a low adoption level. Our research indicates that more efforts to concentrate on this category of farmers by creation extension contact and promoting literacy status could increase adoption. The level of adoption was determined by livestock holding, access to credit, distance from the market and slope of plot, and plot size. This indicates emphasis should be given on adopting livestock-crop based farming system by the farmers due to the complementary effects on each other. Extension agents should increase contacts with farmers and their families, and integrate demonstrations of methods with results.

Our results indicate that in general there is no correlation between probability of adoption and intensity of organic fertilizer application which indicates that factors that affect adoption are not necessarily the same as those that influence the level. Therefore, it is important to consider both stages in evaluating strategies aimed at promoting the adoption and use of organic fertilizer. In general terms, a wide range of factors, policies, institutions and organizations should be organized and coordinated in order to work collaboratively to develop an effective approach to addressing low productivity of crop production.

\section{References}

1. AfDB, (2011): Malawi interim country strategy paper 2011-2012. African Development Bank, Tunis

2. Ajayi, O. C. (2007): User acceptability of sustainable soil fertility technologies: Lessons from farmers' knowledge, attitude and practice in southern Africa. Journal of sustainable agriculture, vol. 30, no. 3, pp. 21-40.

3. Arslan, A., McCarthy, N., Lipper, L., Asfaw, S., Cattaneo, A. (2014): Adoption and intensity of adoption of conservation farming practices in Zambia. Agriculture, Ecosystems \& Environment, Vol. 187, pp. 72-86.

4. Asfaw, A., Admassie, A. (2004): The role of education on the adoption of chemical fertiliser under different socioeconomic environments in Ethiopia. Agricultural Economics, vol. 30, no. 3, pp. 215-228.

5. ATA (Agricultural transforming agency), 2010.Accelerating Ethiopian Agriculture Development for Growth, Food Security, and Equity Synthesis of findings and recommendations for the implementation of diagnostic studies in extension, irrigation, soil health/fertilizer, rural finance, seed systems, and output markets (maize, pulses, and livestock), Addis Ababa, Ethiopia

6. Bationo, A., Hartemink, A., Lungu, O., Naimi, M., Okoth, P. L., Smaling, E., 
Thiombiano, L. (2006): African soils: their productivity and profitability of fertilizer use. Proceedings of the African fertilizer Summit.

7. Beedy, T. L., Snapp, S. S., Akinnifesi, F. K. and Sileshi, G. W. Impact of gliricidia sepium intercropping on soil organic matter fractions in a maize-based cropping system, Agriculture, Ecosystems \& Environment, vol. 138, pp. 139-146.

8. Bezu, S., Kassie, G. T., Shiferaw, B., Ricker-Gilbert, J. (2014): Impact of improved maize adoption on welfare of farm households in Malawi: a panel data analysis. World Development, vol. 59, pp. 120-131

9. Chilot, Y. (2007): The dynamics of soil degradation and incentives for optimal management in the Central Highlands of Ethiopia (Doctoral dissertation, University of Pretoria).

10. Cragg, J. G. (1971): Some statistical models for limited dependent variables with application to the demand for durable goods. Econometrica: Journal of the Econometric Society, pp. 829-844.

11. CSA (Central Statistical Agency) (2011): Statistical Report on Area and Crop Production Addis Ababa, Ethiopia.

12. CSA (Central Statistical Agency), (2015): Agricultural Sample Survey: Report On Farm Management Practices. Addis Ababa, Ethiopia

13. Dawson, N., Martin, A., Sikor, T. (2016):Green Revolution in Sub-Saharan Africa: Implications of Imposed Innovation for the Wellbeing of Rural Smallholders. World Development, vol. 78, pp. 204-218.

14. FEWS NET (Famine Early Warning Systems Network), 2011. Ethiopia Food Security Outlook. http://www.fews.net/docs/Publications/Ethiopia_Dekadal 0820 final ext.pdf

15. Fikru A (2009): Assessment of Adoption Behaviour of Soil and Water Conservation Practices in the Koga Watershed, Highlands of Ethiopia. MSc. Thesis, Cornell University.

16. García-Orenes, F., Morugán-Coronado, A., Zornoza, R., Cerdà, A., Scow, K. (2016): Correction: Changes in Soil Microbial Community Structure Influenced by Agricultural Management Practices in a Mediterranean Agro-Ecosystem. PLoS ONE, vol. 11, no. 3, e0152958. http://doi.org/10.1371/journal.pone.0152958

17. Gebremedhin, B., Swinton, S. M. (2003): Investment in soil conservation in northern Ethiopia: the role of land tenure security and public programs. Agricultural economics, vol. 29, no. 1, pp. 69-84.

18. Geisseler, D., Horwath, W. R., Joergensen, R. G., Ludwig, B. (2010): Pathways of nitrogen utilization by soil microorganisms-a review. Soil Biology and Biochemistry, vol. 42, no. 12, pp. 2058-2067.

19. Greene W (2003): Econometric analysis. $5^{\text {th }}$ Edition. Macmillan, New York, USA.

20. John O, Geophrey S, Mary M (2009): Agricultural technology adoption: A panel analysis of smallholder farmers' fertilizer use in Kenya. Center of Evaluation for 
Global Action. Contributed paper prepared for presentation at the African Economic Research Consortium Conference on Agriculture for Development, May 28th and 29th, Mombasa, Kenya.

21. Kalinda, T., Tembo, G., Kuntashula, E., Lusaka, Z. (2014): Adoption of improved maize seed varieties in Southern Zambia. Asian Journal of Agricultural Sciences, vol. 6, no. 1, pp. 33-39.

22. Kassie, M., Shiferaw, B., Muricho, G. (2011): Agricultural technology, crop income, and poverty alleviation in Uganda. World Development, vol. 39, no. 10, pp. 17841795.

23. Larsen, A. F., Lilleør, H. B. (2014): Beyond the field: The impact of farmer field schools on food security and poverty alleviation. World Development, 64, pp. 843859.

24. Macci, C., Doni, S., Peruzzi, E., Mennone, C., Masciandaro, G. (2013): Biostimulation of soil microbial activity through organic fertilizer and almond tree association. Land Degradation \& Development. vol. 27, pp. 335-345.

25. McIntire, J., Bourzat, D., Prabhu, P. (2016): Crop-livestock interaction in subSaharan Africa. Washington, DC: World Bank.

26. Misiko, M. (2013): Dilemma in participatory selection of varieties. Agricultural Systems, vol. 119, pp. 35-42.

27. Obayelu, A. E., Okuneye, P. A., Shittu, A. M., Afolami, C. A., Dipeolu, A. O. (2016): Determinants and the perceived effects of adoption of sustainable improved food crop technologies by smallholder farmers along the value chain in Nigeria. Journal of Agriculture and Environment for International Development (JAEID), vol. 110, no. 1 , pp. 155-172.

28. Ochi, J. E., Malumfashi, A. J. (2005): Adoption of Selected technologies to Fadama Farming in Bauchi State. In Proceeding of the 9th Annual Conference of Farm Management Association of Nigeria held in Delta State University, Asaba Campus, Asaba Nigeria between pp. 190-195.

29. Ofuoku U, Emuh N and Osuagwu N (2005): Adoption of improved varieties of soybean (Glycine max) among rural female farmers in Ndokwa West and Ukwuani Local Government Areas of Delta State, Nigeria. Proceeding of the 9th Annual conference of Farm management Association of Nigeria held between $18-20^{\text {th }}$ October 2005 at Delta State University, Asaba Campus, Asaba, Nigeria., pp. 257261.

30. Ofuoku,A. U., Olele, N. F., Emah, G.N. (2008): Determinants of adoption of improved fish production technologies among fish farmers in Delta State, Nigeria. Journal of agricultural education and extension, vol. 14, no. 4, pp. 297-306.

31. Otsuka, K., Yamano, T. (2005): The possibility of a green revolution in subSaharan Africa: Evidence from Kenya. Journal of Agricultural and Development Economics, vol. 2, no. 1, pp. 8-19. 
32. Pender, J., Gebremedhin, B. (2008): Determinants of agricultural and land management practices and impacts on crop production and household income in the highlands of Tigray, Ethiopia. Journal of African Economies,vol. 17, no. 3, pp. $395-450$

33. Rufino, M. C., Rowe, E. C., Delve, R. J., Giller, K. E. (2006): Nitrogen cycling efficiencies through resource-poor African crop-livestock systems. Agriculture, ecosystems environment, vol. 112, no. 4, pp. 261-282.

34. Smaling M, Nandwa A and Jansen M (1997): Replenishment soil fertility in Africa. Soil Science Society of America special publication, 5151, pp. 47-61.

35. Spielman, D. J., Byerlee, D., Alemu, D., Kelemework, D. (2010): Policies to promote cereal intensification in Ethiopia the search for appropriate public and private roles. Food Policy, vol. 35, no. 3, pp. 185-194.

36. Storck, H., Doppler, W. (1991): Farming systems and farm management practices of smallholders in the Hararghe Highlands. Wissenschaftsverlag Vauk Kiel, Germany

37. Teklewold H, Dadi L, Yami A and Dana N 2006: Determinants of adoption of poultry technology: a double-hurdle approach. Livestock Research for Rural Development. Volume 18, Article \#40. Retrieved October 5, 2016, from http://www.lrrd.org/ $\underline{\operatorname{lrd} 18 / 3 / \text { tek118040.htm) }}$

38. Teklewold, H., Kassie, M., Shiferaw, B. (2013): Adoption of multiple sustainable agricultural practices in rural Ethiopia. Journal of Agricultural Economics, vol. 64, no. 3, pp. 597-623.

39. Teklewold, H., Kassie, M., Shiferaw, B., Köhlin, G. (2013): Cropping system diversification, conservation tillage and modern seed adoption in Ethiopia: Impacts on household income, agrochemical use and demand for labor. Ecological Economics, vol. 93, pp. 85-93.

40. Tobin, J. (1958): Estimation of relationships for limited dependent variables. Econometrica: journal of the Econometric Society, vol. 26, pp. 24-36.

41. WFP (World Food Program), 2010.The State of Food Insecurity in the World, VialedelleTerme Di Caracalla, 00153 Rome, Italy.

42. World Bank, 2010. Indicators

\section{Appendices}

Appendix Table 1. Summary of hypothetical explanatory variables that affect probability of adoption and intensity use of organic fertilizer.

\begin{tabular}{|l|l|l|l|}
\hline Variable definition & Type of variables & Measurement & $\begin{array}{l}\text { Expected } \\
\text { sign }\end{array}$ \\
\hline Dependent variables & & & \\
\hline Adoption of organic fertilizer $\left.\left(\boldsymbol{D}_{i}^{*}\right) \boldsymbol{D}_{i}^{*}\right)$ & Dummy & Non-adopter =0, adopter=1 & \\
\hline
\end{tabular}




\begin{tabular}{|l|l|l|l|}
\hline $\begin{array}{l}\text { Level of adoption of organic fertilizer }\left(\boldsymbol{D}_{i}^{*}\right) \\
\left.\boldsymbol{D}_{i}^{*}\right)\end{array}$ & Continuous & Quintal & \\
\hline Independent Variables & & & \\
\hline Sex of household & Dummy & Female=0, Male=1 &,+- \\
\hline Age of household & Continuous & Number of years & + \\
\hline Educational status & Dummy & Illiterate=0,Litrate $=1$ & + \\
\hline Family size & Continuous & & Number \\
\hline Experience & Continuous & Number of years &,+- \\
\hline Off/non farm income & Continuous & Ethiopian Birr & + \\
\hline Cultivated land & Continuous & Hectare & - \\
\hline Livestock holding & Continuous & TLU & + \\
\hline Extension contact & Continuous & Number & + \\
\hline Access to credit & Dummy & No=0,yes=1 &,+- \\
\hline Distance to nearest market & Continuous & Kilometre &,+- \\
\hline Plot size & Continuous & Hectare &,++ \\
\hline Average plot distance from home & Continuous & Kilometre &,+- \\
\hline Plot slope & Dummy & Flatter $=0$, steeper $=1$ &,-- \\
\hline Cost of inorganic fertilizer & Continuous & Ethiopian Birr &,-- \\
\hline & & &,++ \\
\hline
\end{tabular}

Appendix Table 2. Estimation assuming independence maximum likelihood estimates of double hurdle model

\begin{tabular}{|l|l|l|l|l|l|l|l|l|l|r|}
\hline Variables & Below & & & & & \multicolumn{2}{|c|}{ Above } & & & \\
\hline Hurdle & coef & SE & P & $\begin{array}{l}\text { lower } \\
\text { CI }\end{array}$ & $\begin{array}{l}\text { upper } \\
\text { CI }\end{array}$ & coefficient & SE & $p$ & \multicolumn{1}{l|l}{$\begin{array}{l}\text { lower } \\
\text { CI }\end{array}$} & upper CI \\
\hline $\begin{array}{l}\text { Age of the } \\
\text { head }\end{array}$ & 0.030 & 0.059 & 0.607 & -0.085 & 0.146 & -0.298 & 0.257 & 0.247 & -0.801 & 0.206 \\
\hline Education & 0.333 & 0.250 & 0.184 & -0.158 & 0.823 & -0.764 & 0.965 & 0.428 & -2.655 & 1.127 \\
\hline Family size & -0.088 & 0.156 & 0.571 & -0.394 & 0.217 & 0.882 & 0.609 & 0.148 & -0.312 & 2.077 \\
\hline Experience & 0.020 & 0.052 & 0.706 & -0.083 & 0.122 & 0.182 & 0.234 & 0.436 & -0.277 & 0.641 \\
\hline $\begin{array}{l}\text { Off/nonfarm } \\
\text { income }\end{array}$ & 0.000 & 0.000 & 0.100 & 0.000 & 0.001 & 0.001 & 0.001 & 0.371 & -0.001 & 0.002 \\
\hline $\begin{array}{l}\text { Size of } \\
\text { cultivated } \\
\text { land }\end{array}$ & 2.252 & 0.929 & 0.015 & 0.432 & 4.072 & -2.203 & 1.259 & 0.080 & -4.671 & 0.266 \\
\hline $\begin{array}{l}\text { Size of } \\
\text { livestock } \\
\text { (TLU) }\end{array}$ & 0.142 & 0.074 & 0.055 & -0.003 & 0.288 & 0.616 & 0.113 & 0.000 & 0.396 & 0.837 \\
\hline $\begin{array}{l}\text { Extension } \\
\text { contact }\end{array}$ & 0.048 & 0.027 & 0.073 & -0.004 & 0.101 & 0.271 & 0.136 & 0.046 & 0.005 & 0.537 \\
\hline Training & 0.743 & 0.623 & 0.233 & -0.477 & 1.964 & -0.454 & 2.686 & 0.866 & -5.718 & 4.810 \\
\hline
\end{tabular}




\begin{tabular}{|l|c|c|c|c|c|r|r|r|r|r|}
\hline Credit & -1.146 & 0.629 & 0.068 & -2.379 & 0.087 & 6.826 & 2.373 & 0.004 & 2.176 & 11.477 \\
\hline $\begin{array}{l}\text { Distance to } \\
\text { the market }\end{array}$ & -0.259 & 0.168 & 0.122 & -0.588 & 0.069 & -0.453 & 0.749 & 0.545 & -1.920 & 1.015 \\
\hline Plot size & -0.556 & 1.658 & 0.738 & -3.805 & 2.694 & 18.009 & 5.441 & 0.001 & 7.345 & 28.673 \\
\hline $\begin{array}{l}\text { Home to plot } \\
\text { distance }\end{array}$ & 0.970 & 0.492 & 0.049 & 0.005 & 1.936 & -3.542 & 1.294 & 0.006 & -6.078 & -1.006 \\
\hline Soil fertility & 1.825 & 0.995 & 0.067 & -0.125 & 3.775 & -4.554 & 3.470 & 0.189 & -11.356 & 2.247 \\
\hline $\begin{array}{l}\text { Slop of the } \\
\text { plot }\end{array}$ & -0.869 & 0.681 & 0.202 & -2.204 & 0.466 & 2.460 & 3.976 & 0.536 & -5.333 & 10.253 \\
\hline Constant & -7.217 & 4.361 & 0.098 & -15.766 & 1.331 & 3.135 & 16.397 & 0.848 & -29.002 & 35.271 \\
\hline Sigma & & & & & & 10.2126 & 0.7418 & 0.0000 & 8.7586 & 11.6665 \\
\hline
\end{tabular}

Source: Double Hurdle Output, 2016

Appendix Table 3. Conversion factors used to calculate Tropical Livestock Units (TLU)

\begin{tabular}{|l|l|}
\hline Animals & TLU-equivalent \\
\hline Calf & 0.25 \\
\hline Heifer and Bull & 0.75 \\
\hline Cows and Oxen & 1 \\
\hline Camel & 1.6 \\
\hline Donkey young & 0.35 \\
\hline Donkey adult & 0.7 \\
\hline Sheep and Goat & 0.13 \\
\hline Chicken/poultry & 0.013 \\
\hline
\end{tabular}

Source: Storck et al., (1991) 